Original Research Paper

\title{
Stable Nitrogen Isotopic Changes in Winter Wheat (Triticum aestivum L.) Induced by its Growth Temperature
}

\author{
${ }^{1,2}$ Zhou Feng Wang, ${ }^{2,3}$ Wei Guo Liu and ${ }^{1,2}$ Rui Juan Hao \\ ${ }^{1}$ Key Laboratory of Subsurface Hydrology and Ecological Effect in Arid Region of Ministry of Education, \\ School of Environmental Science and Engineering, Chang an University, Xi' an, P.R. China \\ ${ }^{2}$ State Key Laboratory of Loess and Quaternary Geology, IEE, CAS, Xi' an, P.R. China \\ ${ }^{3} X i$ ' an Jiaotong University, Xi' an, P.R. China
}

\author{
Article history \\ Received: 23-04-2016 \\ Revised: $17-02-2017$ \\ Accepted: 20-03-2017 \\ Corresponding Author: \\ Zhou Feng Wang \\ Key Laboratory of Subsurface \\ Hydrology and Ecological \\ Effect in Arid Region of \\ Ministry of Education, Chang \\ an University, Xi'an, China \\ Email: wangzf@chd.edu.cn
}

\begin{abstract}
The nitrogen dynamics of plants can be quantified using the variation in their $\delta^{15} \mathrm{~N}$ level. This reveals details of plant physiological characteristics and the relationship between plants and their growth conditions. To better understand plant nitrogen dynamics and the effects of external temperature changes on their nitrogen isotopic composition, we investigated the $\delta^{15} \mathrm{~N}$ characteristics in Triticum aestivum and its mother soils during the plant's life cycle. We found that under field conditions, the plant's leaves and roots $\delta^{15} \mathrm{~N}$ significantly changed. The $\delta^{15} \mathrm{~N}$ values in Triticum aestivum changed from $-1.6 \%$ to $-8.1 \%$ for leaves and from $-2.0 \%$ to $-8.8 \%$ for roots, respectively. $\delta^{15} \mathrm{~N}$ values for both, the leaves and roots were positively correlated with temperature. However, the foliar $\delta^{15} \mathrm{~N}$ corresponded more strongly to air temperature, while the root $\delta^{15} \mathrm{~N}$ corresponded to soil temperature. $\delta^{15} \mathrm{~N}$ values of leaf and root both changed around $0.2 \%$ in response to a 1 degree change in temperature. Plant roots or shoot material cannot reflect the whole plant $\delta^{15} \mathrm{~N}$ values due to a considerable difference between the $\delta^{15} \mathrm{~N}$ values of root and leaf. However, the variations in leaf and root $\delta^{15} \mathrm{~N}$ provide useful proxies to trace seasonal plant nitrogen cycles.
\end{abstract}

Keywords: Nitrogen Isotopic, Winter Wheat, Root, Leaf, Temperature, Wheat Ecophysiology

\section{Introduction}

Nitrogen is considered as an essential nutrient element for plants (Kalcsits et al., 2015). During nitrogen surging of the plant, its $\delta^{15} \mathrm{~N}$ values correlate with changes in the physiological characteristics of the plant (Mariotti et al., 1980; 1982; Evans et al., 1996), the sources of nitrogen and the surrounding environment (Högberg, 1997; Handley et al., 1997; Austin and Vitousek, 1998; Yoneyama, 1996; Amundson et al., 2003; Pardo et al., 2006; Aranibar et al., 2008; Mayor et al., 2014). Consequently, the plant's $\delta^{15} \mathrm{~N}$ composition can be used as a marker to evaluate direction and rate of ecological processes related to isotope fractionation (Tiunov, 2007). Many studies concluded the shift of $\delta^{15} \mathrm{~N}$ values to be related to temperature, precipitation, carbon dioxide in the air, as well as other factors (Martinelli et al., 1999; Aranibar et al., 2008; Liu and Wang, 2010; Meyers et al., 2016). However, the issue of how the environmental factors affect the plants $\delta^{15} \mathrm{~N}$ is still unclear at present (West, 2006; Valery et al., 2008; Zhou et al., 2016).
Temperature has been suggested as one of the key factors influencing $\delta^{15} \mathrm{~N}$ values of plants. Both on a global and regional scale, it was suggested that plants $\delta^{15} \mathrm{~N}$ values usually become high at high Mean Annual Temperature (MAT) (Amundson et al., 2003; Martinelli et al., 1999; Zhou et al., 2016). Similarly, Kohls et al. (1994) found that low temperature could result in negative plants $\delta^{15} \mathrm{~N}$ values. In addition, the results of a past study suggested that $\delta^{15 \mathrm{~N}}$ values of plants and soils became low caused by high rainfall and low temperature at high altitude localities (Mariotti et al., 1980). However, Craine et al. (2015) found that $\delta^{15} \mathrm{~N}$ became enriched with dropping MAP and ascending MAT as MAT is over $-0.5^{\circ} \mathrm{C}$. However, the values were stable for MAT lower than $-0.5^{\circ} \mathrm{C}$. For the Loess Plateau, Liu and Wang (2010) found decreasing $\delta^{15} \mathrm{~N}$ values of plants with increasing MAT. This may be related to the coupled effect of increasing precipitation and temperatures in regions with monsoon climate. These observations show a link between plants and 
environmental factors e.g., temperature. Moreover, the $\delta^{15} \mathrm{~N}$ composition has been established as a useful marker to measure the interaction and correlation between plants in a controlled field environment (Zhou et al., 2016). However, most of the results of stable isotope analysis are based on large scale ecosystem assessment due to natural and anthropogenic processes (Mayor et al., 2014; Robinson, 2001). To our knowledge, there are no studies that demonstrate these relationships between plants and environmental factors. However, differences in $\delta^{15} \mathrm{~N}$ values among plant parts were found in some studies (Kalcsits et al., 2015; Zhou et al., 2016; Yang et al., 2015).

Wish increasing plant age, nitrogen has been shown to move within plant tissues (Larcher, 2002). Few studies have been carried out to examine whether nitrogen transferring within a plant will influence its stable isotopic association (Dawson et al., 2002). Moreover, whether $\delta^{15} \mathrm{~N}$ values remain stable throughout the lifetime of a plant is still unclear. A better understanding of the correlations between nitrogen isotopic fractionations and plant biochemical processes is essential to use $\delta^{15} \mathrm{~N}$ as environmental integrator of nitrogen cycle processes (Meyers et al., 2016).

The total wheat yield is up to $22.5 \%$ of the total grain yield and wheat consumption accounts for $25 \%$ of the total grain consumption in the whole country (Zhao, 1999). In the northern regions of China, winter wheat is typically planted in early October and the subsequent emergence stage ranges from late October to November. Tillering time ranges from December to January and through to early February. Jointing time ranges from late February through to March and April and the flowering stage, filling stage and mature period all range from May to June (Wen, 2013; Li et al., 2014). During the relatively long lifecycle of winter wheat, seasonal temperature change is an important factor to control plant growth and total nitrogen and organic carbon contents. Thus, winter wheat is an ideal plant model to study the influence of the surrounding environment on $\delta{ }^{15} \mathrm{~N}$ values over the lifetime of the plant. To exclude other variables, such as plant species, water status and geographic region, our study featured (1) one single species of winter wheat (Xiaoyan No. 6), (2) water content supplied constantly during the entire wheat growth cycle and (3) using a controlled field plot for the experiment. The study was aimed to investigate possible $\delta 15 \mathrm{~N}$ variation in the development of the plant within the micro-ecosystem and to outline the reasons for $\delta^{15} \mathrm{~N}$ shifts in plants and the controlling factors during the whole growth cycle of winter wheat.

\section{Materials and Methods}

\section{Materials}

We conducted this study in the experimental field belonging to ISWC, CAS in Yangling Zone $\left(34^{\circ} 16^{\prime} \mathrm{N}\right.$, $108^{\circ} 35^{\prime}$ E), Shaanxi Province, China. The studied area lies in the Guanzhong Basin of northwestern China. Here, temperature changes from -12.7 to $37.5^{\circ} \mathrm{C}$ for a year (Zhang et al., 2011), with the maximal temperature in August. The soil type is loessial soil. There are approximately 2196 hours of daylight and 220 frost-free days per year. The annual precipitation and temperature are approximately $660 \mathrm{~mm}$ and $12.9^{\circ} \mathrm{C}$, respectively. Over $50 \%$ of the annual rain falls in the summer season.

Winter wheat is the main crop in this area. The size of the experimental field for this study was $2 \times 3 \mathrm{~m}$. We planted winter wheat Triticum aestivum L. (Xiaoyan No. 6) on October 13th, 2005. Germination occurred on October 27th, 2005. We used approximately $0.01 \mathrm{~kg}$ of urea and diammonium hydrogen phosphate fertilizer per square meter before the harvest. The soil moisture content was strictly controlled at $70-80 \%$ during the whole lifecycle of winter wheat. From October to June of the following year, the winter wheat completed its growth period (Table 1). During the lifetime of winter wheat, air and soil temperatures (at a depth of $10 \mathrm{~cm}$ ) changed from -2.2 to $21.7^{\circ} \mathrm{C}$ and -0.6 to $26.9^{\circ} \mathrm{C}$, with averages of 8.5 and $13.2^{\circ} \mathrm{C}$, respectively. The growing temperature of the plants has been reported by the past study (Zhang et al., 2011).

\section{Sample Collections}

We collected winter wheat Triticum aestivum $L$. (Xiaoyan No. 6) and soil samples after germination from October 27, 2005 to May 30, 2006. We collected leaf, root and soil samples (at depths of 10-20 cm) biweekly. For December, January and February, we collected samples monthly.

We used the flag of leaf for our research. We extracted root samples from the soil as much as possible. We simultaneously collected root area soil, excluding large stones.

\section{Sample Pre-Treatment and Isotope Analysis}

We cleaned leaf and roots samples with de-ionized water. We oven-dried cleaned plant and soil samples $\left(40^{\circ} \mathrm{C}\right)$ for $72 \mathrm{~h}$. We combined 3 to 5 plants as one testing sample and ground the samples in an agate mill.

We analyzed elemental nitrogen contents $(\mathrm{N} \%)$ and the nitrogen isotopic composition $\left(\delta^{15} \mathrm{~N}\right)$ in the Isotope Geochemistry Laboratory, Institute of Earth Environment, CAS, China. We performed all analyses using an Isochron Continuous Flow Stable Isotope Ratio Mass Spectrometer Finnegan Delta Plus coupled with a Flash Elemental Analyzer (EA). We measured the stable isotopic concentrations of $\delta^{15} \mathrm{~N}$ as the ratio of $\delta$-notation relative to the international standard (AIR): 


$$
\delta^{15} N(\%)=\left[\left(\frac{R_{\text {sample }}}{R_{\text {stan dard }}}\right)-1\right] \times 1000
$$

where, $R_{\text {sample }}$ and $R_{\text {standard }}$ are the ${ }^{15} \mathrm{~N} /{ }^{14} \mathrm{~N}$ ratio of the samples and standard, respectively. To compare the difference between the plant $\delta^{15} N$ below ground and above ground, we denoted the differences in leaf and root $\delta^{15} N$ as $\Delta^{15} N_{\text {leaf-root }}$. The standard deviation of $\mathrm{N} \%$ and $\delta^{15} N$ among samples should be below $0.1 \%$ and $0.3 \%$, respectively.

Organic carbon in the soil organic fraction and ammonium and nitrate concentrations were tested at the Institute of Soil and Water Conservation, CAS. Soil organic carbon was determined using the wet combustion method with $\mathrm{K}_{2} \mathrm{Cr}_{2} \mathrm{O}_{7} / \mathrm{H}_{2} \mathrm{SO}_{4}$ and total nitrogen content was determined using the automated Kjeltec (Switzerland Novelact Co. BUCHI322/343, 0$150 \mathrm{mgN}$ ) method (Li et al., 2010). Soil ammonium and nitrate concentrations were determined via the Auto Analyzer 3-aa3 (Germany, Bran + Luebbe Co, Ltd). Precisions were higher than $0.1 \%$ for $\mathrm{N} \%$.

The data for air temperature (air $\mathrm{T}$ ) and soil temperature (soil $\mathrm{T}$ ) at $10 \mathrm{~cm}$ were obtained from the Wugong Meteorological bureau, about $5 \mathrm{~km}$ from the study site. We used an average 10-day air temperature and average $10 \mathrm{~cm}$ soil temperature on the sampling day to examine the relationship between leaf and root $\delta^{15} \mathrm{~N}$ values and growing season temperature variation.

\section{Statistical Analysis}

We performed each set of experiments in triplicate. We present the results for each experiment as the mean \pm SD. We assessed all data using one-way Analysis of Variance (ANOVA) and further analyzed significant results using a multiple comparison test. We determined the relationship between leaf and root $\delta^{15} \mathrm{~N}$ values, as well as air temperature and soil temperature via Spearman rank correlation coefficients. We defined statistical significance at $\mathrm{p}<0.05$. The number of experiments is also indicated in the figure legends. All statistics were computed by SPSS (ver.18.0; SPSS Inc., USA).

\section{Results}

Dynamic Changes and Co-Efficiency between Air and Soil Temperature During Plant Growth

The soil temperature at $10 \mathrm{~cm}$ was higher than air temperature during the wheat growth lifetime. Air temperature changed from -2.2 to $21.7^{\circ} \mathrm{C}$ while soil temperature changed from -0.6 to $26.9^{\circ} \mathrm{C}$, with averages of 8.5 and $13.2^{\circ} \mathrm{C}$, respectively. On October
27,2005 , at the seedling stage of winter wheat, air and soil temperature began to decline. We observed minimal temperatures on December 22, 2005, when winter wheat was at the Tillering stage. From December 23 to May 30, 2006, temperatures rose and the winter wheat completed its Jointing stage, flowering stage, Filling stage and mature period (Table 1 and Fig. 1A).

The temperature changing pattern for air is very similar to that of soil. In general, air $\mathrm{T}$ positively correlated with soil $\mathrm{T}(\mathrm{r}=0.985, \mathrm{p}<0.01$, Fig. 1B)
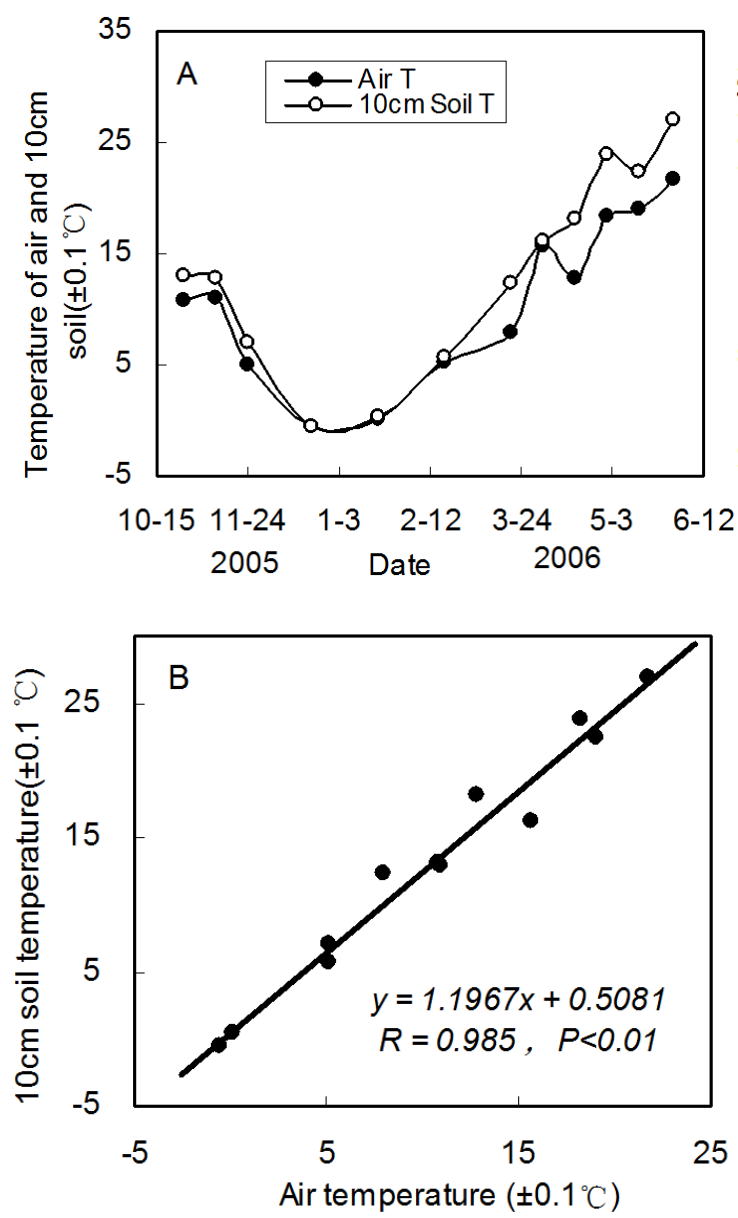

Fig. 1. Air T (10-day average) and soil T (sample collection day) changes during the vegetative period (A). Air T and soil $T$ have a significant positive correlation $(\mathrm{p}<0.01)(\mathrm{B})$

Table 1. Winter wheat vegetative period in the northwestern parts of China (Jing et al., 2013)

\begin{tabular}{ll}
\hline Time periods & Winter wheat vegetative period \\
\hline October, November & Seedling stage \\
December, January, early February & Tillering stage \\
In late February, March, July & Jointing stage \\
Early May & Flowering stage \\
In late May, June & Filling stage, mature period \\
\hline
\end{tabular}




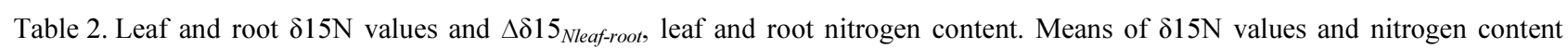
throughout vegetative period are shown on the bottom row. Data given are means $\pm \mathrm{SE}(\mathrm{n}=3)$

\begin{tabular}{|c|c|c|c|c|c|}
\hline Date & Leaf $\delta^{15} \mathrm{~N}(\%)$ & $\operatorname{Root} \delta^{15} \mathrm{~N}(\%)$ & $\begin{array}{l}\text { Leaf nitorgen } \\
\text { content }(\%)\end{array}$ & $\begin{array}{l}\text { Leaf nitorgen } \\
\text { content }(\%)\end{array}$ & $\begin{array}{l}\Delta \delta^{15} N_{\text {Leaf-Root }} \\
(\mathbf{\%})\end{array}$ \\
\hline $27-10-2005$ & $-3.0 \pm 0.5$ & $-2.0 \pm 0.2$ & $6.8 \pm 0.5$ & $1.7 \pm 0.1$ & -1.0 \\
\hline $10-11-2005$ & $-5.6 \pm 0.1$ & $-4.4 \pm 0.1$ & $4.7 \pm 0.3$ & $1.8 \pm 0.1$ & -1.2 \\
\hline $24-11-2005$ & $-7.7 \pm 1.5$ & $-6.4 \pm 0.2$ & $4.7 \pm 0.4$ & $1.7 \pm 0.1$ & -1.3 \\
\hline $22-12-2005$ & $-8.1 \pm 0.3$ & $-8.8 \pm 0.4$ & $4.0 \pm 0.3$ & $1.5 \pm 0.1$ & 0.8 \\
\hline 20-01-2006 & $-8.1 \pm 0.1$ & $-7.9 \pm 0.2$ & $2.8 \pm 0.2$ & $1.8 \pm 0.1$ & -0.2 \\
\hline $19-02-2006$ & $-4.2 \pm 0.8$ & $-6.6 \pm 0.3$ & $4.8 \pm 0.2$ & $1.4 \pm 0.1$ & 2.4 \\
\hline $20-03-2006$ & $-3.7 \pm 0.2$ & $-3.9 \pm 0.2$ & $5.9 \pm 0.5$ & $1.2 \pm 0.0$ & 0.2 \\
\hline 03-04-2006 & $-3.8 \pm 0.1$ & $-5.6 \pm 0.1$ & $5.1 \pm 0.2$ & $1.3 \pm 0.2$ & 1.8 \\
\hline $17-04-2006$ & $-2.0 \pm 0.1$ & $-4.0 \pm 0.2$ & $4.8 \pm 0.3$ & $1.0 \pm 0.1$ & 2.0 \\
\hline $01-05-2006$ & $-3.2 \pm 0.2$ & $-6.8 \pm 0.4$ & $5.0 \pm 0.1$ & $1.0 \pm 0.0$ & 3.7 \\
\hline $15-05-2006$ & $-1.6 \pm 0.1$ & $-3.6 \pm 0.4$ & $3.4 \pm 0.4$ & $0.9 \pm 0.0$ & 2.0 \\
\hline $30-05-2006$ & $-2.3 \pm 0.7$ & $-2.3 \pm 0.2$ & $0.8 \pm 0.0$ & $1.0 \pm 0.1$ & 0.0 \\
\hline Average & $-4.4 \pm 2.4$ & $-5.2 \pm 2.2$ & $4.4 \pm 1.5$ & $1.4 \pm 0.3$ & $0.8 \pm 1.6$ \\
\hline
\end{tabular}

Table 3. Soil $\delta^{15} \mathrm{~N}$ values, nitrogen content, nitrate content, ammonium content, carbon content and $\mathrm{C} / \mathrm{N}$ ratios. Means of index are shown at the bottom row. Data given are means $\pm \mathrm{SE}(\mathrm{n}=3)$

\begin{tabular}{|c|c|c|c|c|c|c|}
\hline Date & $\begin{array}{l}\text { Soil } \delta^{15} \mathrm{~N} \\
(\% \mathrm{o})\end{array}$ & $\begin{array}{l}\text { Soil nitorgen } \\
\text { content }(\%)\end{array}$ & $\begin{array}{l}{\text { Soil } \mathrm{NO}_{3}^{-}}^{-} \\
\text {content }(\mathrm{mg} / \mathrm{kg})\end{array}$ & $\begin{array}{l}\text { Soil } \mathrm{NH}_{4}^{+} \\
\text {content }(\%)\end{array}$ & $\begin{array}{l}\text { Soil Organic } \\
\text { carbon content (\%o) }\end{array}$ & Soil C/N \\
\hline $27-10-2005$ & $5.7 \pm 0.3$ & 0.13 & 42.79 & 104.26 & 1.05 & 7.97 \\
\hline $10-11-2005$ & $3.9 \pm 0.6$ & 0.14 & 43.59 & 55.45 & 0.98 & 7.01 \\
\hline $24-11-2005$ & $4.9 \pm 0.6$ & 0.14 & 40.85 & 51.27 & 1.07 & 7.67 \\
\hline $22-12-2005$ & $3.8 \pm 0.2$ & 0.14 & 42.26 & 28.56 & 0.76 & 5.58 \\
\hline $20-01-2006$ & $4.6 \pm 0.7$ & 0.15 & 39.97 & 87.44 & 1.00 & 6.61 \\
\hline $19-02-2006$ & $3.1 \pm 1.5$ & 0.12 & 42.80 & 20.31 & 1.01 & 8.16 \\
\hline $20-03-2006$ & $3.7 \pm 0.2$ & 0.13 & 43.84 & 19.86 & 1.05 & 8.21 \\
\hline 03-04-2006 & $3.7 \pm 0.8$ & 0.12 & 44.36 & 18.15 & 0.98 & 8.33 \\
\hline $17-04-2006$ & $4.5 \pm 0.3$ & 0.13 & 41.66 & 23.03 & 1.01 & 7.76 \\
\hline 01-05-2006 & $3.9 \pm 0.4$ & 0.11 & 20.28 & 19.16 & 1.01 & 8.80 \\
\hline $15-05-2006$ & $4.5 \pm 0.2$ & 0.11 & 18.42 & 16.05 & 1.05 & 9.17 \\
\hline $30-05-2006$ & $4.5 \pm 0.1$ & 0.11 & 12.03 & 13.41 & 1.02 & 9.10 \\
\hline Average & $4.2 \pm 0.1$ & $0.13 \pm 0.01$ & $36.07 \pm 11.76$ & $38.08 \pm 30.31$ & $1.00 \pm 0.08$ & $7.86 \pm 1.05$ \\
\hline
\end{tabular}

Signatures of $\delta^{15} N$ and Nitrogen Contents in the Flag of Leaf and Root Winter Wheat (Triticum Aestivum)

The flag of leaf and root nitrogen content varied from 0.8 to $6.8 \%$ and 0.9 to $1.8 \%$, respectively (Table 2). During the wheat lifecycle, foliar nitrogen content (N\%) is higher than root nitrogen content (Table 1) with average nitrogen contents of leaf and root of 4.4 and $1.4 \%$, respectively. The highest leaf nitrogen content appeared at the seedling stage (October 27, 2005), while the lowest foliar nitrogen content appeared at the mature period (May 30, 2006).

The foliar $\delta^{15} \mathrm{~N}$ values ranged from $-1.6 \%$ to $-8.1 \%$ o with an average of $-4.4 \%$. Root $\delta^{15} \mathrm{~N}$ values vary from $-2.0 \%$ to $-8.8 \%$ with an average of $-5.2 \%$ (Table 1 ). Minimal foliar and root $\delta^{15} \mathrm{~N}$ values appeared in December and January, when winter wheat was in its Tillering stage. We found maximal leaf and $\operatorname{root} \delta^{15} \mathrm{~N}$ values during the mature period (May, 2006) (Table 1). However, leaf and root $\delta^{15} \mathrm{~N}$ values co-varied over the lifetime (Fig. 2).
The $\Delta^{15} N_{\text {leaf-root }}$ shows that $\delta^{15} \mathrm{~N}$ values of the root were above that of leafs during the sprouting stage (from 2005-10 to 2006-01). However, the values of foliar $\delta^{15} \mathrm{~N}$ were above those of the roots at tillering stage (from 2006-02 to 2006-05). Minimal foliar and root $\delta^{15} \mathrm{~N}$ values appeared in December and January (Table 1 and Fig. 3), when the temperature was lowest during the experimental year. During the wheat lifetime, $\delta^{15} \mathrm{~N}$ values display a large shift between the wheat leaf and root (Table 1).

\section{Values of $\delta^{15} N$ Positively Correlated with Air and Soil Temperature with the Growth of Winter Wheat}

To further investigate the plant $\delta^{15} \mathrm{~N}$ changes during the lifetime of winter wheat, we performed a correlation analysis on the values of $\delta^{15} \mathrm{~N}$ and temperature of air and soil with every developmental stage, respectively. We detected significant positive correlations between the leaf $\delta^{15} \mathrm{~N}$ level and the temperatures of air and root $\delta^{15} \mathrm{~N}$ level and soil $(\mathrm{r}=$ $0.84, \mathrm{p}<0.01$ for leaf $\delta^{15} \mathrm{~N}$ and air $\mathrm{T}$ and $\mathrm{r}=0.68$, $\mathrm{p}<0.05$ for root $\delta^{15} \mathrm{~N}$ and soil T, respectively) (Fig. 3 
and 4). Similarly, we obtained the leaf $\delta^{15} \mathrm{~N}$ and root $\delta^{15} \mathrm{~N}$ with air and soil temperature as follows:

$$
\begin{aligned}
& \delta^{15} \mathrm{~N}_{\text {leaf }}=0.2 \mathrm{~T}_{\text {air }}-7.0 \\
& \delta^{15} \mathrm{~N}_{\text {root }}=0.2 \mathrm{~T}_{\text {soil }}-7.3
\end{aligned}
$$

where, $\delta^{15} N_{\text {leaf }}$ and $\delta^{15} N_{\text {root }}$ are the leaf and root $\delta^{15} N$ values, respectively. $T_{\text {air }}$ is the air temperature and $T_{\text {soil }}$ is the soil temperature at a depth of $10 \mathrm{~cm}$, respectively. From formula (1) and (2), we conclude that the $\delta^{15} \mathrm{~N}$ values of leaf and root changed by $0.2 \%$ in response to a temperature change of $1^{\circ}$.

Soil Physicochemical Characteristics and Correlation with Changes of Winter Wheat $\delta^{15} \mathrm{~N}$ Values during Plant Growth Stage

The soil $\delta^{15} \mathrm{~N}$ values range from $3.1 \%$ to $5.7 \%$, with an average of $4.2 \%$. $\delta^{15} \mathrm{~N}$ values in soil only slightly changed, compared to plant flag leaf and root $\delta^{15} \mathrm{~N}$ values. Soil nitrogen contents and organic carbon contents in soil also changed only slightly with averages of 0.13 and $1.0 \%$, respectively. The contents of soil $\mathrm{NO}_{3}$ $\mathrm{N} \%$ and $\mathrm{NH}_{4}{ }^{-} \mathrm{N} \%$ ranged from 44.36 to $12.03 \mathrm{mg} / \mathrm{kg}$ and 104.26 to 13.41 , respectively.

Soil $\delta^{15} \mathrm{~N}$ values were higher than leaf and $\operatorname{root} \delta^{15} \mathrm{~N}$ values (Table 1 and 2). However, the significant correlation were not find between temperature and soil $\delta^{15} \mathrm{~N}, \mathrm{~N} \%, \mathrm{NO}_{3}-\mathrm{N} \%$ and $\mathrm{NH}_{4}-\mathrm{N} \%$ ( $\mathrm{p}>0.05$ for all). Soil $\delta^{15} \mathrm{~N}, \mathrm{~N} \%, \mathrm{NO}_{3}-\mathrm{N} \%$ and $\mathrm{NH}_{4}-\mathrm{N} \%$ do not correspond to leaf and root $\delta^{15} \mathrm{~N}$. Interestingly, the carbon to nitrogen ratios correlate with leaf and $\operatorname{root} \delta^{15} \mathrm{~N}(\mathrm{p}<0.05$; Fig. 3).

Table 4 Correlations between leaf and root $\delta^{15} \mathrm{~N}$ values and soil chemical indicators. * and ** means the difference is significant at the 0.05 and 0.01 level, respectively.

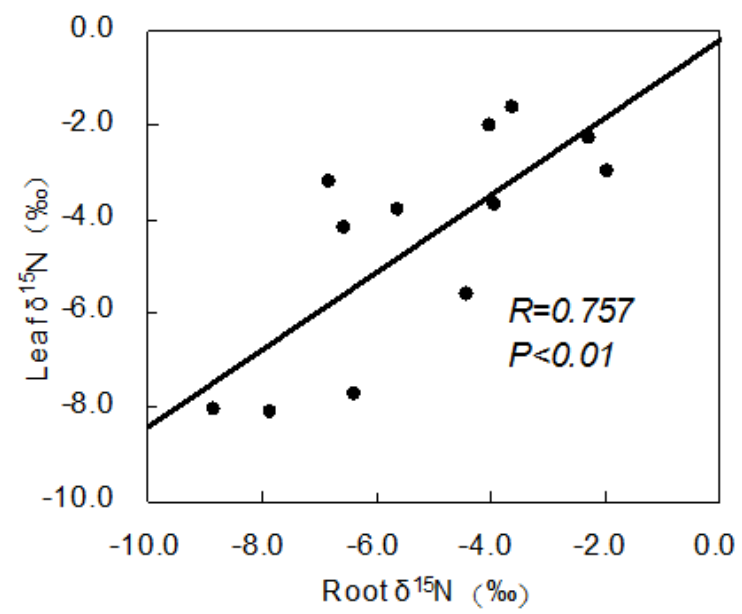

Fig. 2. Correlations between leaf and $\operatorname{root} \delta^{15} \mathrm{~N}$ values. A significant positive correlation was found between leaf and $\operatorname{root} \delta^{15} \mathrm{~N}$ values $(\mathrm{p}<0.01)(\mathrm{B})$

\section{Discussion}

Deficiency of nitrogen is known to limit plant growth in terrestrial ecosystems (Vitousek, 1994; Kalcsits et al., 2015). Improved understanding of the mechanisms that control the whole-plant and foliar $\delta^{15} \mathrm{~N}$ will be gained from plant nitrogen acquisition and allocation (Handley and Raven, 1992; Evans, 2001; Dawson et al., 2002; Kalcsits et al., 2014). Plant nitrogen dynamics can be quantified by natural variation in the plant's nitrogen isotopic composition (Evans et al., 1996; Kalcsits et al., 2015). In this study, we mainly researched the relationship between temperature and plant $\delta^{15} \mathrm{~N}$ values, excluding other influences like external air factors. We tested $\delta^{15} \mathrm{~N}$ values of wheat from seedling stage to mature period. Our results show that plant $\delta^{15} \mathrm{~N}$, of leafs and roots are all positively correlated with air and soil temperatures.

Changes of Plant $\delta^{15} N$ Values during Growing Time and its Influencing Factors

A large body of work exists thatstudues changes in nitrogen isotopic compositions in various plants under different environmental conditions (Pardo et al., 2006; Amundson et al., 2003; Mariotti et al., 1980; Austin and Vitousek, 1998; Austin and Sala, 1999; Handley et al., 1999; Swap et al., 2004; Aranibar et al., 2004; 2008). However, few studies concentrate on changes in nitrogen isotopic compositions throughout the whole lifecycle of plants. In this study, we measured $\delta^{15} \mathrm{~N}$ values of winter wheat at different developmental stages. Our results show that large shifts in $\delta^{15} \mathrm{~N}$ values exist in wheat leaves and roots during the lifecycle of the plants (Table 1). Leaf and root $\delta^{15} \mathrm{~N}$ values decreased from $-8.1 \%$ to $-1.6 \%$ and from $-8.8 \%$ to $-2.0 \%$, respectively. We observed minimal $\delta^{15} \mathrm{~N}$ values at tillering stages of winter wheat. This implies that plant physiological varieties changed due to changes in surrounding environmental factors. On the other hand, we measured maximal $\delta^{15} \mathrm{~N}$ values in seedling stages and mature periods. Thus, the level of $\delta^{15} \mathrm{~N}$ corresponds to the developmental stage.

The winter wheat $\delta^{15} \mathrm{~N}$ values in leaves and root vary systematically with temperature changes (Fig. 3). Increasing temperature is a controlling factor for stable varied $\delta^{15} \mathrm{~N}$ as soil moisture content and nutrient level are constant. Winter wheat showed lower $\delta^{15} \mathrm{~N}$ values during the cold season (From December to January), implying increased isotopic discrimination during this period. Our result is similar with finding that plants under cold stress have low foliar $\delta^{15} \mathrm{~N}$ values (Kohls et al., 1994). A study reported that the plants under slow growing rate have large nitrogen isotopic fractionation (Domenach et al., 1989). The metabolism of plants usually slows down in cold season and consequently, the nutrient uptake evidently decreases. 

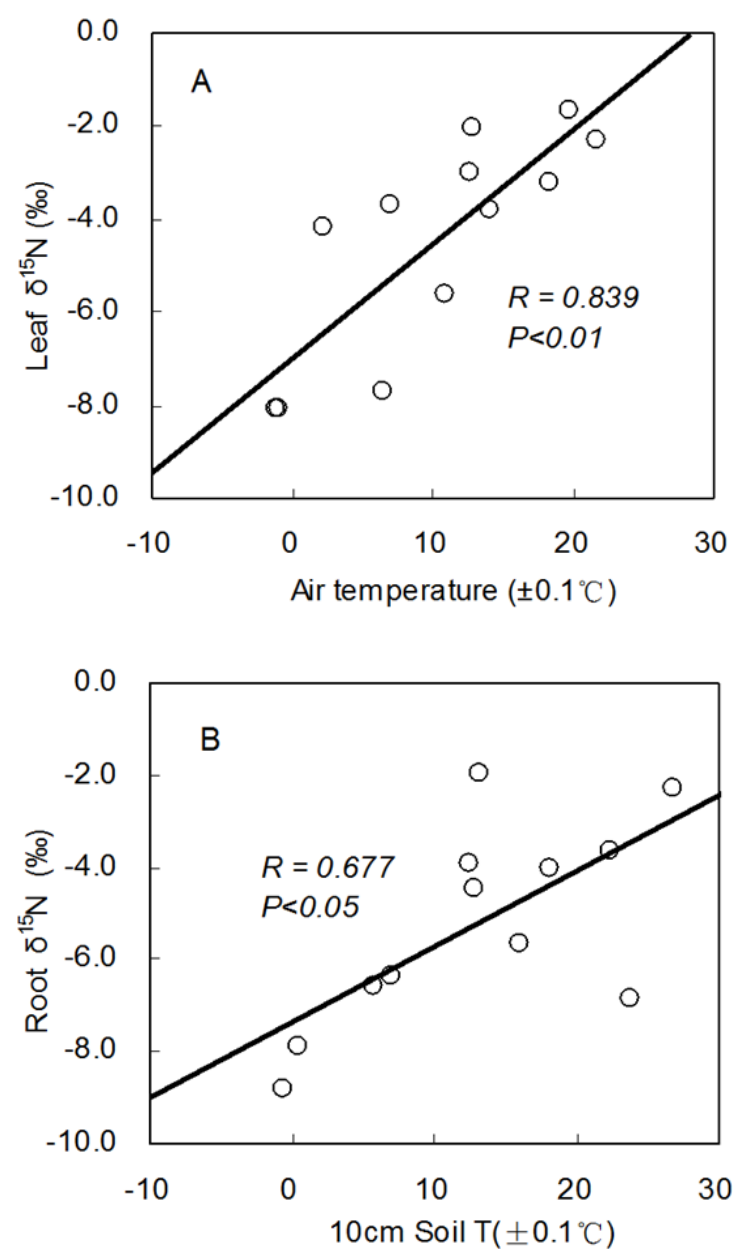

Fig. 3. Correlations of leaf $\delta^{15} \mathrm{~N}$ values and air temperature (A), root $\delta^{15 \mathrm{~N}}$ values and soil temperature (B). The correlation significant of leaf's are higher $(A, p<0.01)$ than those for root's $(B, p<0.05)$. The results implies that the isotopic compositions in the leaf are more sensitive to temperature changes

Table 4. Correlations between leaf and root $\delta^{15} \mathrm{~N}$ values and soil chemical indicators. * and $* *$ means the difference is significant at the 0.05 and 0.01 level, respectively

\begin{tabular}{llllllll}
\hline Soil & Soil & Soil & \multicolumn{2}{c}{ Soil } & $\mathrm{NO}_{3}{ }^{-}$ & & \\
& $\delta^{15} \mathrm{~N}$ & $\mathrm{~N}$ & $\mathrm{NO}_{3}{ }^{-}$ & $\mathrm{NH}_{4}{ }^{+}$ & $+\mathrm{NH}_{4}{ }^{+}$ & $\mathrm{C} \%$ & $\mathrm{C} / \mathrm{N}$ \\
\hline Leaff ${ }^{15} \mathrm{~N}$ & 0.06 & $-0.77^{* *}$ & -0.48 & -0.41 & -0.49 & 0.47 & $0.83^{* *}$ \\
Root $\delta^{15} \mathrm{~N}$ & 0.46 & -0.48 & -0.28 & -0.04 & -0.06 & $0.58^{*}$ & $0.62^{*}$ \\
\hline
\end{tabular}

The relatively small nitrogen uptake by plants then increases isotope discrimination (Mariotti et al., 1982), which leads to decreasing $\delta^{15} \mathrm{~N}$ values in cold temperatures. Furthermore, the rate of nitrogen uptake decreased in plants, but nitrate reductase activity boosted significantly when temperature became low (Yaneva et al., 2002; Schmidt et al., 2015). Increased nitrate of reductase activity in plants in cold environment may resulted in increased nitrogen discrimination between plants and soil.
Certain plant required for vernalization stage, which will lead them to enter the reproductive stage through exposure the plant to low, but non-freezing temperatures (Trione, 1966; Streck et al., 2003). Vernalization influences most of the plant's chemical patterns, which associated with plant's metabolic adaptations under low temperature. Vernalization of winter wheat happens during the tillering stage in cold season. Secondary, the study showed that secondary metabolite (like lipids, amino sugars and alkaloids) have more negative $\delta^{15} \mathrm{~N}$ values (Roland et al., 2002), which may lead to decreasing $\delta^{15} \mathrm{~N}$ values in colder temperatures.

\section{Influence of Nitrogen Source from Soil on Plant $\delta^{15} N$}

In general, nitrogen in plants comes from soil nitrogen pool (Vallano and Sparks, 2013). Variations in the soil nitrogen stock may change wheat $\delta^{15} \mathrm{~N}$ in our study. Nitrogen in soil exists both in organic and inorganic nitrogen forms. However, there was not significant correlation between wheat $\delta^{15} \mathrm{~N}$ and total soil nitrogen $\delta^{15} \mathrm{~N}$ in our study. The reason may be that the plant can only absorb inorganic nitrogen from minor amino acids in soil. Our results show that lower soil $\delta^{15} \mathrm{~N}$ values appear during December, January and February when air and soil temperatures are low (Table 2 and Fig. 1). Plants take up low $\delta^{15} \mathrm{~N}$ nitrogen sources $\left(\mathrm{NH}_{4}{ }^{+}-\mathrm{N}\right.$, $\mathrm{NO}_{3}{ }^{-} \mathrm{N}$ ), which in turn leads to lower wheat $\delta^{15} \mathrm{~N}$ during low temperature seasons. In contrast, plants have higher $\delta^{15} \mathrm{~N}$ values when the surrounding temperatures increase. However, the $\delta^{15} \mathrm{~N}$ values of leaf and root do not correspond to nitrogen contents and soil chemical characteristics. When soil organic matter decomposes, nitrification, denitrification and ammonia volatilization result in ${ }^{15} \mathrm{~N}$ enrichment in the soil (Austin and Vitousek, 1998; Craine et al., 2015). The results in this study show that $\delta^{15} \mathrm{~N}$ values of leaves and roots were lower than soil $\delta^{15} \mathrm{~N}$, which is testified in other studies (Evans and Ehleringer, 1993; Garten, 1993; Högberg and Johannisson, 1993; Michelsen et al., 1998; Miller and Bowman, 2002; Koba et al., 2003).

Our results showed that soil $\mathrm{C} / \mathrm{N}$ ratios vary in relation to changes in growing temperature and wheat $\delta^{15} \mathrm{~N}$ values (Table 4). Consequently, changes in leaf and root $\delta^{15} \mathrm{~N}$ values within the lifecycle are correlated to the soil $\mathrm{C} / \mathrm{N}$ and their coefficients of determination $(R)$ are $0.83(\mathrm{p}<0.05)$ and $0.62 \quad(\mathrm{p}<0.05)$, respectively. We suspect this to be related to microbial activity and litter decomposition (Rustad et al., 2000; Keryn, 2001; Craine et al., 2015). At low temperatures, microbial activity weakens (Panikov et al., 2006) and the low decomposition rate reduces soil nitrogen availability and decreases soil carbon to nitrogen ratios.

Temperature influences microbial activity, which influences plant's nitrogen sources in the soil. For example, organic matter decomposition, inorganic nitrogen concentration etc. So the main external cause of 
wheat $\delta^{15} \mathrm{~N}$ changes might comes from nitrogen source changes in the soil.

\section{Leaf and Root $\delta^{15} N$ Variation}

The previous study showed that the variation in plant $\delta^{15} \mathrm{~N}$ can range from $-10 \%$ and $10 \%$ (Evans, 2001). In this study, $\Delta^{15} N_{\text {Leaf-Root }}$ values range from -1.3 to $3.7 \%$ (Table 1), which is consistent with previous reports (Evans et al., 1996; Dijkstra et al., 2003; Kalcsits et al., 2015). However, during early wheat growth periods in seeding stage, $\delta^{15} \mathrm{~N}$ values of roots are higher than $\delta^{15} \mathrm{~N}$ values of leafs. During later growth periods, the leaf $\delta^{15} \mathrm{~N}$ values are higher than the root $\delta^{15} \mathrm{~N}$ values. In this study, the enrichment of $\delta^{15} \mathrm{~N}$ from roots to leaves (Table 1 ) is different with previous studies (Yoneyama and Kaneko, 1989; Robinson et al., 1998; 2000; Peuke et al., 2006). Our results further confirm that above-ground tissue $\delta^{15} \mathrm{~N}$ values cannot represent the $\delta^{15} \mathrm{~N}$ values of the whole plant (Dijkstra et al., 2003). Intra-plant patterns of $\delta^{15} \mathrm{~N}$ can be influenced by changes of nitrogen sources and reallocated of nitrogen in its vegetative period (Shearer and Kohl, 1986; Evans, 2001; Schmidt et al., 2015). Plant's assimilation patterns between $\mathrm{NH}_{4}{ }^{+}$and $\mathrm{NO}_{3}{ }^{-}$can influence intra-plant $\delta^{15} \mathrm{~N}$ either (Evans et al., 1996; Kalcsits et al., 2015). Urea we used to fertilize the experimental plot in our study may explain the negative $\Delta^{15} N_{\text {Leaf-Root }}$ values in seedling stage because that is when we applied the fertilizer. Previous study shows that fractionation of ${ }^{14} \mathrm{~N}$ and ${ }^{15} \mathrm{~N}$ could occur at two pathways. One is come from plant uptake nitrogen from a medium into root cells the other lies in subsequent enzymatic assimilation into other nitrogen forms (Mariotti et al., 1980; 1982). Compared with $\mathrm{NH}_{4}^{+}, \mathrm{NO}_{3}{ }^{-}$ assimilation can take place in both roots and shoots. Then the left $\mathrm{NO}_{3}^{-}$that was not assimilated in the root would have higher $\delta^{15} \mathrm{~N}$ values. Therefore the $\delta^{15} \mathrm{~N}$ of $\mathrm{NO}_{3}{ }^{-}$available for assimilation into the leaf is greater than that for the root when the enriched nitrogen in ${ }^{15} \mathrm{~N}$ is transferred to the leaf and assimilated. Nitrogen reallocation during plant growth can lead to differences among plant organs, because most biochemical reactions in plant tissues discriminate against ${ }^{15} \mathrm{~N}$. $\mathrm{NO}_{3}{ }^{-}$reduction, GS-GOGAT, transaminations and other enzymatic reactions could result in products with lower $\delta^{15} \mathrm{~N}$ values compared with the original source (Evans, 2001; Schmidt et al., 2015). Reallocation of nitrogen from leafs to flowers and seeds, during the jointing, flowering and filling stages as well as during the mature period of winter wheat, cause higher leaf $\delta^{15} \mathrm{~N}$ values than in the root.

\section{Conclusion}

To our knowledge, this is the first study to present a correlation between the shift in $\delta^{15} \mathrm{~N}$ values of the leaf and root of winter wheat under water-controlled conditions and during the plant's whole lifecycle. We found that both leaf and root $\delta^{15} \mathrm{~N}$ values are positively correlated to growing temperature during the lifecycle of winter wheat. The range of wheat $\delta{ }^{15} \mathrm{~N}$ values is higher in colder seasons than in warm seasons. The change in leaf and root $\delta^{15} \mathrm{~N}$ appears to be influenced by plant ecophysiology and the $\mathrm{C} / \mathrm{N}$ ratio in the soil, which is related to air temperature. However, the large shift in $\delta^{15} \mathrm{~N}$ values between root and leaf implies that plant root or shoot material does not represent the $\delta^{15} \mathrm{~N}$ values of the whole plant. Consequently, additional experiments are needed to better understand correlation between plant $\delta^{15} \mathrm{~N}$ and the surrounding environmental factors.

\section{Acknowledgement}

We would like to thank Dr. Zhonghai Yang and Xiangzhong Li for their critical discussions throughout this project and thoughtful reviews of this manuscript. We also thank Zheng Wang for his help for samples analysis in the laboratory.

\section{Funding Information}

This research was supported by the National Science Foundation of China (NSFC, Grant No. 41202164, 41373022), Special Fund for Basic Scientific Research of Central Colleges, Chang'an University (Grant No 2013G1291069) and the Open Research Fund of Key Laboratory of Subsurface Hydrology and Ecological Effect in Arid Region, Ministry of Education (Grant No 2013G1502041).

\section{Author Contributions}

Zhou Feng Wang and Wei Guo Liu: Designed and performed experiments and wrote the paper.

Zhou Feng Wang and Rui Juan Hao: Analyzed data and wrote the paper.

\section{Ethics}

This article is original and contains unpublished materials. The corresponding author confirms that all of the other authors have read and approved the manuscript and no ethical issues involved.

\section{References}

Amundson, R., A.T. Austin, A.G. Schuur, K. Yoo and V. Matzek et al., 2003. Global patterns of the isotopic composition of soil and plant nitrogen. Global Biogeochem Cy., 17: 31-1-30-10.

DOI: $10.1029 / 2002$ GB001903 
Aranibar, J.N., I.C. Anderson, H.E. Epstein, C.J.W. Feral and R.J. Swap et al., 2008. Nitrogen isotope composition of soils, $\mathrm{C}_{3}$ and $\mathrm{C}_{4}$ plants along land use gradients in southern Africa. J. Arid Environ., 72: 326-337. DOI: 10.1016/j.jaridenv.2007.06.007

Aranibar, J.N., L. Otter, S.A. Macko, C.J.W. Feral and H.E. Epstein et al., 2004. Nitrogen cycling in the soil-plant system along a precipitation gradient in the Kalahari sands. Global Change Biol., 10: 359-373. DOI: $10.1111 / \mathrm{j} .1365-2486.2003 .00698 . x$

Austin, A.T. and O.E. Sala, 1999. Foliar $\mathrm{d}^{15} \mathrm{~N}$ is negatively correlated with rainfall along the IGBP transect in Australia. Aust. J. Plant Physiol., 26: 293-295. DOI: 10.1071/PP98144

Austin, A.T. and P.M. Vitousek, 1998. Nutrient dynamics on a precipitation gradient in Hawai'i. Oecologia, 113: 519-529. DOI: 10.1007/s004420050405

Craine, J.M., E.N.J. Brookshire, M.D. Cramer, N.J. Hasselquist and K. Koba et al., 2015. Ecological interpretations of nitrogen isotope ratios of terrestrial plants and soils. Plant Soil, 228: 1-26. DOI: $10.1007 / \mathrm{s} 11104-015-2542-1$

Dijkstra, P., C. Williamson, O. Menyailo, R. Doucett and G. Koch et al., 2003. Nitrogen stable isotope composition of leaves and roots of plants growing in a forest and a meadow. Isotopes Environ. Health Stud., 39: 29-39.

DOI: $10.1080 / 1025601031000102189$

Domenach, A.M., F. Kurdali and R. Bardin, 1989. Estimation of symbiotic dinitrogen fixation in alder forest by the method based on natural ${ }^{15} \mathrm{~N}$ abundance. Plant Soil, 118: 51-59.

DOI: 10.1007/BF02232790

Dawson, T.E., S. Mambelli, A.H. Plamboeck, P.H. Templer and K.P. Tu, 2002. Stable isotopes in plant ecology. Annu. Rev. Ecol. Syst., 33: 507-559. DOI: 10.1146/annurev.ecolsys.33.020602.095451

Evans, R.D. and J.R. Ehleringer, 1993. A break in the nitrogen cycle in aridlands? Evidence from $\delta \mathrm{p}^{15} \mathrm{~N}$ of soils. Oecologia, 94: 314-317. DOI: $10.1007 / \mathrm{BF} 00317104$

Evans, R.D., 2001. Physiological mechanisms influencing plant nitrogen isotope composition. Trends Plant Sci., 6: 121-126. DOI: $10.1016 / \mathrm{S} 1360-1385(01) 01889-1$

Evans, R.D., A.J. Bloom, S.S. Sukrapanna and J.R. Ehleringer, 1996. Nitrogen isotope composition of tomato (Lycopersicon esculentum Mill. cv. T-5) grown under ammonium or nitrate nutrition. Plant Cell Environ., 19: 1317-1323.

DOI: $10.1111 / \mathrm{j} .1365-3040.1996 . t b 00010 . x$

Garten, C.T.J., 1993. Variation in foliar ${ }^{15} \mathrm{~N}$ abundance and the availability of soil nitrogen on walker branch watershed. Ecology, 74: 2098-2113.

DOI: $10.2307 / 1940855$
Handley, L.L. and J.A. Raven, 1992. The use of natural abundance of nitrogen isotopes in plant physiology and ecology. Plant Cell Environ, 15: 965-985. DOI: $10.1111 /$ j.1365-3040.1992.tb01650.x

Handley, L.L., A.T. Austin, D. Robinson, C.M. Scrimgeour and J.A. Raven et al., 1999. The $15 \mathrm{~N}$ natural abundance $\left(\delta^{15} \mathrm{~N}\right)$ of ecosystem samples reflects measures of water availability. Aust. J. Plant Physiol., 26: 185-199. DOI: 10.1071/PP98146

Handley, L.L., D. Robinson, B.P. Forster, R.P. Ellis and C.M. Scrimgeour et al., 1997. Shoot $\delta^{15} \mathrm{~N}$ correlates with genotype and salt stress in barley. Planta, 201: 100-102. DOI: $10.1007 / \mathrm{BF} 01258686$

Högberg, P. and C. Johannisson, 1993. ${ }^{15} \mathrm{~N}$ abundance of forests is correlated with losses of nitrogen. Plant Soil, 157: 147-150. DOI: 10.1007/BF02390237

Högberg, P., 1997. 15N natural abundance in soil-plant systems. New Phytol., 137: 179-203. DOI: 10.1046/j.1469-8137.1997.00808.x

Jing, Y.G., J.Z. Fan and M.S. Gao, 2013. Influences of the climate warming on developmental stages of winter wheat in Shaanxi. J. Triticeae Crops, 33: 389-396.

Kalcsits, L.A, H.A. Buschhaus and R.D. Guy, 2014. Nitrogen isotope discrimination as an integrated measure of nitrogen fluxes, assimilation and allocation in plants. Physiol. Plant, 151: 293-304. DOI: $10.1111 / \mathrm{ppl} .12167$

Kalcsits, L.A., X. Min and R.D. Guy, 2015. Interspecific variation in leaf-root differences in $\delta^{15} \mathrm{~N}$ among three tree species grown with either nitrate or ammonium. Trees, 29: 1-10. DOI: $10.1007 / \mathrm{s} 00468-015-1186-3$

Keryn, P., 2001. Temperature and moisture effects on decomposition. Proceedings of the NEE Workshop, (EEW' 01), pp: 95-102.

Koba, K., M. Hirobe, L. Koyama, A. Kohzu and N. Tokuchi et al., 2003. Natural ${ }^{15} \mathrm{~N}$ abundance of plants and soil $\mathrm{N}$ in a temperate coniferous forest. Ecosystems, 6: 457-469. DOI: $10.1007 / \mathrm{s} 10021-002-0132-6$

Kohls, S.J., C. van Kessel, D.D. Baker, D.F. Grigal and D.B. Lawrence, 1994. Assessment of $\mathrm{N}_{2}$ fixation and $\mathrm{n}$ cycling by Dryas along a chronosequence within the forelands of the athabasca glacier, Canada. Soil Biol. Biochem., 26: 623-632. DOI: 10.1016/0038-0717(94)90251-8

Li, H.M., Y.S. Jing and M.S. Gao, 2014. Characteristics of heat resources in winter wheat growing seasons and its impacts in Guanzhong area over last 40 years. J. Arid Land Resources Environ., 28: 140-144.

Li, S.J., L.P. Qiu and X.C. Zhang, 2010. Mineralization of soil organic carbon and its relations with soil physical and chemical properties on the Loess Plateau. Acta Ecologica Sinica, 30: 1217-1226. 
Liu, X.Z. and G.A. Wang, 2010. Measurements of nitrogen isotope composition of plants and surface soils along the altitudinal transect of the eastern slope of Mount Gongga in Southwest China. Rapid Commu. Mass Spectrometry, 24: 3063-3071. DOI: 10.1002/rcm.4735

Martinelli, L.A., M.C. Piccolo, A.R. Townsend, P.M. Vitousek and E. Cuevas et al., 1999. Nitrogen Stable Isotopic Composition of Leaves and Soil: Tropical Versus Temperate Forests. In: New Perspectives on Nitrogen Cycling in the Temperate and Tropical Americas: Report of the International Scope Nitrogen Project, Townsend, A.R. (Ed.), Springer Science and Business Media, Dordrecht, ISBN-10: 0792357043, pp: 45-65.

Mariotti, A., F. Mariotti, M.L. Champigny, N. Amarger and A. Moyse, 1982. Nitrogen isotope fractionation associated with nitrate reductase activity and uptake of $\mathrm{NO}_{3}{ }^{-}$by pearl millet. Plant Physiol., 69: 880-884. DOI: $10.1104 /$ pp.69.4.880

Mariotti, A.D., J.C. Pierre, V.S. Bruckert and J. Guillemot, 1980. The abundance of natural nitrogen 15 in the organic matter of soils along an altitudinal gradient (Chablais, Haute Savoie, France). Catena, 7: 293300. DOI: 10.1016/S0341-8162(80)80020-8

Mayor, J.R., S.J. Wright, E.A. Schuur, M.E. Brooks and B.L. Turner, 2014. Stable nitrogen isotope patterns of trees and soils altered by long-term nitrogen and phosphorus addition to a lowland tropical rainforest. Biogeochemistry, 119: 293-306. DOI: $10.1007 / \mathrm{s} 10533-014-9966-1$

Meyers, L.M., A.M. Nahlik and E.S. Dekeyser, 2016. Relationship between the natural abundance of soil nitrogen isotopes and condition in North Dakota wetlands. Ecol. Indicators, 60: 394-401.

DOI: $10.1016 /$ j.ecolind.2015.06.042

Michelsen, A., C. Quarmby, D. Sleep and S. Jonasson, 1998. Vascular plant ${ }^{15} \mathrm{~N}$ natural abundance in heath and forest tundra ecosystems is closely correlated with presence and type of mycorrhizal fungi in roots. Oecologia, 115: 406-418.

DOI: $10.1007 / \mathrm{s} 004420050535$

Miller, A.E. and W.D. Bowman, 2002. Variation in nitrogen-15 natural abundance and nitrogen uptake traits among co-occurring alpine species: Do species partition by nitrogen form? Oecologia, 130: 609-616. DOI: 10.1007/s00442-001-0838-8

Panikov, N.S., P.W. Flanagan, W.C. Oechel, M.A. Mastepanov and T.R. Christensen, 2006. Microbial activity in soils frozen to below $-39^{\circ} \mathrm{C}$. Soil Biol. Biochem., 38: 785-794.

DOI: 10.1016/j.soilbio.2005.07.004

Pardo, L.H., P.H. Templer, C.L. Goodale, S. Duke and P.M. Groffman et al., 2006. Regional assessment of $\mathrm{N}$ saturation using foliar and root $\delta \delta^{15} \mathrm{~N}$. Biogeochemistry, 80: 43-171.

DOI: $10.1007 / \mathrm{s} 10533-006-9015-9$
Peuke, A.D., A. Gessler and H. Rennenberg, 2006. The effect of drought on $\mathrm{C}$ and $\mathrm{N}$ stable isotopes in different fractions of leaves, stems and roots of sensitive and tolerant beech ecotypes. Plant Cell Environ., 29: 823-835.

DOI: $10.1111 / \mathrm{j} .1365-3040.2005 .01452 . \mathrm{x}$

Robinson, D., 2001. $\delta^{15} \mathrm{~N}$ as an integrator of the nitrogen cycle. Trends Ecol. Evol., 16: 153-162.

DOI: 10.1016/S0169-5347(00)02098-X

Robinson, D., L.L. Handley and C.M. Scrimgeour, 1998. A theory for ${ }^{15} \mathrm{~N} /{ }^{14} \mathrm{~N}$ fractionation In nitrate-grown vascular plants. Planta, 205: 397-406.

DOI: $10.1007 / \mathrm{s} 004250050336$

Robinson, D., L.L. Handley, C.M. Scrimgeour, D.C. Gordon and B.P. Forster et al., 2000. Using stable isotope natural abundances $\left(\delta^{15} \mathrm{~N}\right.$ and $\left.\delta^{13} \mathrm{C}\right)$ to integrate the stress responses of wild barley (Hordeum spontaneum C. Koch.) genotypes. J. Exp. Bot., 51: 41-50. DOI: 10.1093/jexbot/51.342.41

Roland, B., M. Ashmore, S. Braun, W. Flückiger and I.J.J. Van den. Wyngaert, 2003. Empirical nitrogen Critical Loads for Natural and Semi-Natural Ecosystems: 2002 Update. In: Empirical Critical Loads for Nitrogen. Swiss Agency for Environment, Achermann, B. and R. Bobbink (Eds.), Forest and Landscape SAEFL, Berne, pp: 43-170.

Rustad, L.E., J.L. Campbell, G.M. Marion, R.J. Norby and M.J. Mitchell et al., 2000. A meta-analysis of the response of soil respiration, net nitrogen mineralization and aboveground plant growth to experimental ecosystem warming. Oecologia, 126: 543-562. DOI: $10.1007 / \mathrm{s} 004420000544$

Schmidt, H.L., R.J. Robins and R.A. Werner, 2015. Multi-factorial in vivo stable isotope fractionation: Causes, correlations, consequences and applications. Isotopes Environ. Health Stud., 51: 155-199. PMID: 25894429

Shearer, G. and D. H. Kohl, 1986. N2-Fixation in field settings: Estimations based on natural $15 \mathrm{~N}$ abundance. Aus. J. Plant Physiol., 13: 699-756. DOI: 10.1071/PP9860699

Streck, N.A., A. Weiss and P.S. Baenziger, 2003. A generalized vernalization response function for winter wheat. Agron. J., 95: 155-159. DOI: 10.2134/agronj2003.1550

Swap, R.J., J.N. Aranibar, P.R. Dowty, W.P. Gilhooly and S.A. Macko, 2004. Natural abundance of ${ }^{13} \mathrm{C}$ and ${ }^{15} \mathrm{~N}$ in $\mathrm{C}_{3}$ and $\mathrm{C}_{4}$ vegetation of southern Africa: patterns and implications. Global Change Biol., 10: 250-358. DOI: 10.1111/j.1365-2486.2003.00702.x

Tiunov, A.V., 2007. Stable isotopes of carbon and nitrogen in soil ecological studies. Biol. Bull., 4: 475-489. DOI: 10.1134/S1062359007040127

Trione, E.J., 1966. Metabolic changes associated with vernalization of wheat. I. Carbohydrate and nitrogen patterns. Plant Physiol., 41: 277-281. PMID: 16656251 
Valery, J.T., Z. Eshetu, A. Colman, T. Bekele and A. Gezahgne et al., 2008. Reconstructing palaeo environment from $\delta^{13} \mathrm{C}$ and $\delta^{15} \mathrm{~N}$ values of soil organic matter: A calibration from arid and wetter elevation transects in Ethiopia. Geoderma, 147: 197-210. DOI: 10.1016/j.geoderma.2008.09.001

Vallano, D.M. and J.P. Sparks, 2013. Foliar $\delta^{15} \mathrm{~N}$ is affected by foliar nitrogen uptake, soil nitrogen and mycorrhizae along a nitrogen deposition gradient. Oecologia, 172: 47-58. PMID: 23070141

Vitousek, P.M., 1994. Beyond global warming: Ecology and global change. Ecology, 75: 1861-1876. DOI: $10.2307 / 1941591$

Larcher, W., 2002. The Utilization of Mineral Elemments. In: Physiological Plant Ecology: Ecophysiology and Stress Physiology of Functional Groups, W. Larcher (Ed.), Springer Berlin Heidelberg, Germany, pp: 203-207.

Wen, L., 2013. Climate change impact on winter wheat in shaanxi province [D]. Yangling, China, North West Agriculture and Forestry University.

West, J.B., G.J. Bowen, T.E. Cerling and J.R. Ehleringer, 2006. Stable isotopes as one of nature's ecological recorders. Trends Ecol. Evolut., 21: 408-414. DOI: $10.1016 /$ j.tree.2006.04.002

Yaneva, I.A., G.W. Hoffmann and R. Tischner, 2002. Nitrate reductase from winter wheat leaves is activated at low temperature via protein dephosphorylation. Physiol. Plantarum, 114: 65-72. DOI: 10.1034/j.1399-3054.2002.1140110.x
Yang, Y., R.T.W. Siegwolf and C. Koerner, 2015. Species specific and environment induced variation of $\delta(13) \mathrm{C}$ and $\delta(15) \mathrm{N}$ in alpine plants. Front Plant Sci., 6: 423-423. DOI: 10.3389/fpls.2015.00423

Yoneyama, T. and A. Kaneko, 1989. Variations in the natural abundance of $15 \mathrm{~N}$ in nitrogenous fractions of komatsuna plants supplied with nitrate. Plant Cell Physiol., 32: 1211-1217.

DOI: 10.1093/oxfordjournals.pcp.a077840

Yoneyama, T., 1996. Characterization of Natural 15N Abundance of Soils. In: Mass Spectrometry of Soils, Boutton, T.W. and S. Yamasaki (Eds.), Marcel Dekker, New York, USA, ISBN-10: 0824796993, pp: 205-223.

Zhang, L.W., C.Y. Song and J.P. Yan, 2011. Spatiotemporal trends of annual extreme temperature in Northern and Southern Qinling mountains. Scientia Geographica Sinica, 31: 1007-1011.

Zhao, G.C., 1999. Research progress and Prospect of wheat cultivation in China. Crops, 1999: 5-7.

Zhou, Y.C., X.L. Cheng, J.W. Fan and Harris Wa, 2016. Patterns and controls of foliar nitrogen isotope composition on the Qinghai-Tibet plateau, China. Plant Soil., 406: 265-276.

DOI: $10.1007 / \mathrm{s} 11104-016-2882-5$ 